\title{
THE EFFECT OF SERVICE QUALITY ON RE-BUYING IN LAZADA'S ONLINE SHOPPING WITH CUSTOMER SATISFACTION AS A MEDIATION VARIABLES
}

\author{
Rosita Wahyuni a \\ a Magister of Management, Ahmad Dahlan University \\ Email : rositawahyuni39@gmail.com
}

\begin{abstract}
This study aims to test: 1). The Effect of Service Quality on Repurchase Intention. 2). Effect of Service Quality on Customer Satisfaction. 3). The Effect of Consumer Satisfaction on Repurchase Interest. 4). The Effect of Service Quality on Repurchase Interest is mediated by Customer Satisfaction. The sampling technique used non-probability sampling method, namely accidental sampling, with a sample of 150 respondents. The analysis method used is simple linear regression and multiple linear regression. The data used are primary data using a questionnaire for data collection. Based on the results of data analysis, it shows that Service Quality (X) has a positive effect on Repurchase Interest (Y). Service Quality (X) has a positive effect on Customer Satisfaction (Z). Consumer Satisfaction (Z) has a positive effect on Repurchase Interest (Y). Customer Satisfaction (Z) fully mediates between Service Quality (X) and Repurchase Interest (Y). This is because when a comparison is made between the direct effect and the indirect effect, the coefficient value of Service Quality (X) has decreased and the significance value, which was initially significant, becomes insignificant.
\end{abstract}


Keywords: Service Quality, Customer Satisfaction, and Repurchase Interest.

\section{INTRODUCTION}

In line with the development of economy, technology and culture in this modern era, the number of internet users is increasing drastically from day to day. The number of users that continues to grow is a potential market share. This phenomenon is of course a business opportunity for several parties who then seize the opportunity by providing or or creating an online store. E-commerce is one of the innovations that emerged as a result of advances in technology itself.One of the well-known online shops in Indonesia is Lazada. Lazada offers several necessities such as cellphones / tablets, household appliances, health and beauty, men's and women's fashion, baby and children's equipment, electronics, food and beverage, automotive, music media and books. The number of facilities presented by Lazada increasingly makes consumers interested in shopping at Lazada, and Lazada is the main choice for consumers to shop online, this can be seen from Figure 1.3 which illustrates the percentage of the main choices for online stores, (www.lazada.co.id).

Lazada is a subsidiary of Rocket Internet, a company from Germany. Lazada is one of the online shops in the Top Brand Award category. Top Brand Award is an award given to brands of consumer choice. According to research conducted by Frontier Consulting Group from 2016 to 2018, Lazada with the top brand index in 2016 was $29.3 \%$, in 2017 it was $20.4 \%$, and in 2018 it was $31.8 \%$. The following is the top brand index data on the online shop in 2016-2018 as follows:

Top Brand Index Data for 2016 - 2018 


\begin{tabular}{|l|l|l|l|}
\hline Brand & $\begin{array}{l}\mathbf{2 0 1 6} \\
\text { year }\end{array}$ & $\begin{array}{l}\mathbf{2 0 1 7} \\
\text { year }\end{array}$ & $\begin{array}{l}\mathbf{2 0 1 8} \\
\text { year }\end{array}$ \\
\hline Lazada & $29.3 \%$ & $20.4 \%$ & $31.8 \%$ \\
\hline OLX & $27.7 \%$ & $17.3 \%$ & - \\
\hline Pedia shop & $11.4 \%$ & $19.4 \%$ & $18.5 \%$ \\
\hline Bukalapak & $6.8 \%$ & $8.1 \%$ & $8.7 \%$ \\
\hline Blibli & $4.0 \%$ & $6.0 \%$ & $8.0 \%$ \\
\hline
\end{tabular}

Source: Top Brand Index

For a company, achieving consistently improved performance requires efforts to create superior value for its customers in a sustainable manner. To maximize the company's performance in the long term, the company must continue to build and maintain profitable cooperation with its customers.

Service quality greatly affects consumer repurchase interest. besides that, it is stated that if the customer is satisfied with the quality of the service provided, customer loyalty will arise so that the customer's buying interest increases and makes the customer repurchase again. If the customer or consumer feels good about the quality of service, then the customer or consumer will make repeated purchases and promote word of mouth to relatives or colleagues ${ }^{1}$ (Griffin, 2003).

Service quality also affects consumer satisfaction in online shopping at Lazada. Satisfaction is a feeling of pleasure or disappointment for someone who arises after comparing the performance of the product / service which is considered the performance of the expected product / service ${ }^{1}$, argues that service quality is the level of good and bad conditions of the offerings provided by the seller in order to satisfy consumers

\footnotetext{
${ }^{1}$ Kotler, P. \& Keller, KL (2006). Marketing management. (12th edition). Upper Saddle River: Pearson Education, Inc.
} 
by providing or conveying consumer desires or demands that exceed what consumers expect. Quality of service provides an incentive to customers to forge a strong bond with the company in the long run. This bond allows the company to carefully understand customer expectations in creating customer satisfaction.

Factors that greatly influence repurchase interest are customer satisfaction. customer is someone who continuously and repeatedly comes to the same place to satisfy his desires by having a product or getting a service. The concept of customer satisfaction is important for marketing managers where customer satisfaction can encourage repeat purchases.

Several studies have found that service quality has a significant effect on repurchase interest, among others: ${ }^{2}$, there is a positive effect of service quality on repurchase interest. Putri argues that service quality has a significant effect on repurchase interest. argues that service quality has a significant positive effect on repurchase interest 3 .

Several studies have found that service quality has a very significant effect on consumer satisfaction, among others: argue that together or simultaneously all dimensions or service quality have a significant effect on customer satisfaction. Aliyyah argues that service quality consisting of physical evidence, reliability, responsiveness, assurance and empathy has a significant effect on customer satisfaction. argues that

2 Aditya L (2008) Analysis of the Effect of Service Quality on Repurchase Interest in Empirical Studies at Pt.Sriwijaya Air, Semarang District. Journal of Business Strategy Vol. 17 No. 2

${ }^{3}$ Putri, et.al (2015) Analysis of Service Quality on Consumer Purchase Intention (Case Study of Gramedia Bookstore Colonel Atmo Palembang). STIE Multi Data, Palembang. 
service quality has a positive and significant impact on customer satisfaction ${ }^{4}$.

Several studies have found that consumer satisfaction has a significant effect on repurchase interest, among others: Agustiani, argues that there is a positive effect of consumer satisfaction on repurchase interest ${ }^{5}$. Riko and Rahayu argue that customer satisfaction has a positive effect on repurchase interest $^{6}$. Arfiani and Sjaharuddin state that consumer satisfaction has a partially significant effect on repurchase interest ${ }^{7}$.

In addition, several studies have found that service quality has an effect on repurchase interest in mediation by customer satisfaction, among others: Riko, states that service quality has a significant positive effect on repurchase intention through mediating customer satisfaction ${ }^{8}$. service quality has a significant effect on repurchase interest by mediating consumer satisfaction. Pratiwi states that there is a significant

\footnotetext{
${ }^{4}$ Aliyyah (2017). The influence of service quality on customer satisfaction on consumers of The Little A Coffee Shop Sidoarjo. Journal of Business Administration (JAB) Vol. 51 No. 2

${ }^{5}$ Agustiani (2014). The effect of customer satisfaction on the interest in buying re-purchases on the Lion Air airline in Jakarta. Journal of Economics, Management and Accounting Vol. 9 No.3

${ }^{6}$ Riko (2013). The Effect of Service Quality and Perceived Value on Repurchase Intention through Mediation of Customer Satisfaction at Solaria Restaurant in Surabaya. Journal Of Business And Banking Volume 3, No. 2.

${ }^{7}$ Arfiani \& Herman (2015). The Effect of Product Quality and Service Quality on Customer Satisfaction and Buyback Intention at Padamcdonald's Alauddin Makassar. Journal of Organization and Management Vol 3 September, 2015

${ }^{8}$ Riko (2013). The Effect of Service Quality and Perceived Value on Repurchase Intention through Mediation of Customer Satisfaction at Solaria Restaurant in Surabaya. Journal Of Business And Banking Volume 3, No. 2.
} 
positive effect of service quality on repurchase interest through mediating consumer satisfaction ${ }^{9}$.

\section{LITERATURE REVIEW}

\section{Repurchase Interests}

Purchase intention is a mental statement from consumers that reflects the purchase plan for a product with certain brands. So, if someone wants to buy it is usually influenced by factors such as encouragement and certain considerations. stated that buying interest is the stage of the respondent's tendency to act before the buying decision is actually implemented. Purchase intention contained in a person to carry out a behavior is influenced by attitudes and other variables.

The high interest in repurchasing will have a positive impact on the success of the product in the market. Repurchase interest is customer behavior in which customers respond positively to the quality of a company's products / services and intend to re-consume the company's products 10 .

According to Ferdinand repurchase interest can be identified through the following indicators ${ }^{11}$ :

1) Transactional Interests, namely the tendency for someone to repurchase products that have been consumed.

2) Referential interest, namely the tendency of a person to reference a product he has bought, so that other

\footnotetext{
${ }^{9}$ Pratiwi, et.al (2016). The Effect of Service Quality and Customer Satisfaction on the Intention to Buy Drugs at the Orchid Pharmacy Depo Dr. Hasan Sadikin, Bandung. Indonesian Journal of Clinical Pharmacy Vol.5 No. 1

${ }^{10}$ Cronin, J Joseph, Jr, and Steven A Taylor (1992). Measuring Service Quality: A Reexamination and Extension, Journal Of Marketing vol 56.

${ }^{11}$ Ferdinand, A. 2002. Structural Equation Modeling in Management Research, 2nd edition BP UDIP: Semarang.
} 
people buy it with a reference to his consumption experience.

3) Preferential interest, namely interest that describes the behavior of a person who always has a primary preference for the products he has consumed, this preference can only be replaced if something happens with the reference product.

4) Explorative Interest, which is an interest that describes the behavior of a person who is always looking for information about the product he is interested in and looking for information to support the positive properties of the product he handles.

\section{Quality of Service}

Service Quality is the level of service opportunity, which on the one hand can lead to satisfaction of each customer according to the satisfaction of the average population, and on the other hand the procedures for its implementation are in accordance with the established standards and code of ethics. And service quality is a necessity that companies must do in order to be able to survive and still get customer trust. Consumption patterns and customer lifestyles require companies to be able to provide quality services.

If the service received or felt is as expected, then the service quality is perceived as good and satisfying. The satisfaction that is formed can encourage customers to make repeat purchases and will later become loyal customers ${ }^{12}$. This is in line with the results of research conducted by Murakami ${ }^{13}$ which show that service quality greatly affects repurchase interest. Service quality is a necessity that companies must do

\footnotetext{
${ }^{12}$ Kotler, P. \& Keller, KL (2006). Marketing management. (12th edition). Upper Saddle River: Pearson Education, Inc.

${ }^{13}$ Murakami (2017). The Effect of Service Quality on Consumer Repurchase Interest at Asuka Restaurant Cibitung: Bina Nusantara University, Bekasi Utara.
} 
in order to be able to survive and still get the trust of customers ${ }^{14}$. Consumption patterns and customer lifestyles require companies to be able to provide quality services ${ }^{15}$.

\section{Customer Satisfaction}

Consumer satisfaction is the level of consumer feelings after comparing what is received and The creation of customer satisfaction can provide several benefits for the relationship between companies and customers to be harmonious, provide a good basis for repeat purchases and create customer satisfaction and form a word of mouth recommendation that is beneficial for service. one of the benefits of customer satisfaction is that it can lead to repeat purchases. The level of customer satisfaction will have an impact on increasing feelings of loyalty by consumers and cause consumers to return to the same place to make repeat purchases. Customers will feel satisfied if their expectations are met or will be very satisfied if their expectations are exceeded. This is in line with the results of research conducted by, Rahmat $\mathrm{H}^{16}$, which shows that customer satisfaction is very influential on repurchase interest. With the existence of high customer satisfaction, it can increase the high interest in consumer repurchase ${ }^{17}$.

\footnotetext{
${ }^{14}$ Zulfan A (2017) The effect of e-service quality on the interest in purchasing Muslim clothing products in Indonesian lazada from an Islamic perspective: UII Yogyakarta

${ }^{15}$ Wendo (2018) The Effect of Service Quality on Repurchase Interest at Puti Minang Raja Basa Restaurant in Bandar Lampung. UIN Raden Intan, Lampung. ${ }^{16}$ Rahmat H (2015). The effect of consumer satisfaction on the decision to purchase Philips lamps (case study on Telkom University students). Ecodemica V ol 3. N o.1

${ }^{17}$ Ida M. The Effect of Perceptions of Quality and Customer Satisfaction on Repurchase Intention of Pepsodent Toothpaste : Faculty of Economics, Unika Santo Thomas, North Sumatra
} 


\section{Quality of Service}

Services / services are all actions or performance that one party can offer to another party which is essentially intangible and does not result in any ownership ${ }^{18}$ (Kotler 2009: 36).

service quality can be interpreted as a measure of how good the level of service provided is in accordance with customer expectations. Consumers form service expectations from many sources, such as past experiences, word of mouth and advertisements. Whether or not the quality of service depends on the ability of service providers to consistently meet customer expectations.

\section{The Effect of Service Quality on Repurchase Interest}

Regarding the relationship between these two things, it can be said that a service product has an impact on the willingness to use the same service in the Because basically past behavior can directly influence interest (intention) and future behavior (future behavior).

actually the relationship between the customer and the company will be stronger when the customer has a good assessment of the quality of service provided by the company and vice versa is getting weaker when the customer or customer has a negative assessment of quality services provided by the company.

Several research results indicate an influence between service quality on repurchase interest ${ }^{19}$, which show that

\footnotetext{
${ }^{18}$ Kotler, P. \& Keller, KL (2006). Marketing management. (12th edition). Upper Saddle River: Pearson Education, Inc.

${ }^{19}$ Putri, et.al (2015) Analysis of Service Quality on Consumer Purchase Intention (Case Study of Gramedia Bookstore Colonel Atmo Palembang). STIE Multi Data, Palembang
} 
service quality greatly affects repurchase interest ${ }^{20}$. An indication of the effect of service quality on purchase intention is also in the conclusions obtained from research conducted. In this study they show that perceptions of quality have an influence on consumer purchase interest. on bank customers also shows that perceptions of bank service quality have a significant impact on customer loyalty to the bank concerned. Thus it can be said that the quality of services provided by the company will be able to influence consumer interest in reusing the company's products. Based on the description above, the hypothesis can be formulated as follows:

\section{H1: Service quality has a significant effect on repurchase interest}

\section{The Effect of Service Quality on Customer Satisfaction}

Besides influencing repurchase interest, service quality also affects customer satisfaction. There are several empirical studies that support that service quality affects customer satisfaction, argued that service quality has a positive and significant impact on customer satisfaction ${ }^{21}$.

The relationship between service quality and customer satisfaction is important for companies and researchers, because companies (service providers) need to know whether the company's goal is to have consumers who are satisfied with the company's performance or provide "perceived service quality" at the maximum level ${ }^{22}$. Service quality has a very close relationship with customer satisfaction, that is, quality encourages consumers to undergo a strong relationship with

\footnotetext{
${ }^{20}$ Wendo (2018) The Effect of Service Quality on Repurchase Interest at Puti Minang Raja Basa Restaurant in Bandar Lampung. UIN Raden Intan, Lampung. ${ }^{21}$ Destiana (2018). The influence of service quality on guest satisfaction at Niagara Parapat Hotel, North Sumatra Province.JOM FISIP Vol. 5 No. 1

${ }^{22}$ Cronin, J Joseph, Jr, and Steven A Taylor (1992). Measuring Service Quality: A Reexamination and Extension, Journal Of Marketing vol 56.
} 
the company. In the long term this kind of bonding allows the company to carefully understand the expectations of consumers and their needs.Based on the description above, the hypothesis can be formulated as follows:

\section{H2: Service Quality Has Significant Influence on Consumer Satisfaction}

\section{Definition of Consumer Satisfaction}

According to Kotler, consumer satisfaction is the level of a person's feelings after comparing (performance or results) that is felt compared to expectations ${ }^{23}$. Consumer satisfaction can be defined as an evaluation of consumer awareness and love for goods or services that have been delivered to the Satisfaction is influenced by the level of expectations for service quality ${ }^{24}$.

According to Lovelock's opinion quoted by Tjiptono $i^{25}$, there are several methods to evaluate satisfaction, including:

1) Performance, the main characteristics of a product and is the main characteristic that consumers consider in buying a product

2) Additional characteristics or features (Features), from basic functions related to product choices and their development, namely secondary or complementary characteristics

3) Reliability (Reability), the small possibility of a product or service being damaged or

\footnotetext{
${ }^{23}$ Kotler, P. \& Keller, KL (2006). Marketing management. (12th edition). Upper Saddle River: Pearson Education, Inc.

${ }^{24}$ Cronin, J Joseph, Jr, and Steven A Taylor (1992). Measuring Service Quality: A Reexamination and Extension, Journal Of Marketing vol 56.

25 Tjiptono and Chandra. 2011. Service, Quality and Satisfaction (3rd ed). Yogyakarta: Andi.
} 
malfunctioning within a certain period of time and under certain conditions

4) Easy to repair (serviceability), including speed, competence, comfort, easy repair, and satisfying complaint handling

5) Aesthetics, the attractiveness of a product according to consumer's senses, for example, design and color models ${ }^{26}$.

\section{The Effect of Customer Satisfaction on Repurchase Interest}

Consumer satisfaction is very important for companies because customer satisfaction is the main driver of postpurchase phenomena such as re-purchase intentions. consumers feel a certain level of satisfaction or dissatisfaction that will influence subsequent behavior such as repeat purchases. The intention to buy back a product or service will appear when the consumer

Several studies state that high consumer satisfaction can increase consumer repurchase interest ${ }^{27}$, states that customer satisfaction has a partially significant effect on repurchase interest ${ }^{28}$. Based on the description above, the hypothesis can be formulated as follows:

\section{H3: Consumer Satisfaction has a significant effect on repurchase interest}

\footnotetext{
26 Tjiptono and Chandra. 2011. Service, Quality and Satisfaction (3rd ed). Yogyakarta: Andi.

27 Rahmat H (2015). The effect of consumer satisfaction on the decision to purchase Philips lamps (case study on Telkom University students). Ecodemica V ol 3. N o.1

${ }^{28}$ M. Irzad (2018). The Influence of Customer Satisfaction on Food Repurchase Interest at Ayam Bakar Wong Solo Restaurant, Alauddin, Makassar City.Journal of Profitability, Faculty of Economics and Business Volume 2 No 1
} 


\section{The Effect of Service Quality on Repurchase Interest in Mediation by Customer Satisfaction}

Service quality is an effort to fulfill the needs and desires of consumers and the accuracy of its delivery to balance consumer expectations. Customer satisfaction is a level where the needs, wants and expectations of consumers can be met which will result in repeat purchases or continued loyalty. the most important factor for creating customer satisfaction is the performance of the agent which is usually defined by the quality of the agent.

The role of consumer satisfaction as a mediation is very necessary to see whether the desires and expectations of consumers have been met, seeing from the quality of services provided by the company, it can affect consumers in making repeat purchases. This can be seen based on some of the results of previous research, among others, according to: Jocellynne ${ }^{29}$ which states that there is a significant positive effect of service quality on repurchase interest through mediating consumer satisfaction $^{30}$.

\section{H4: Service Quality Has Significant Impact on Repurchase Interest with Customer Satisfaction as a Mediation Variable}

\section{Framework}

The thinking framework is a conceptual model of how the theory relates to various factors that have been identified as important problems. The thinking framework will

\footnotetext{
${ }^{29}$ Jocellynne (2018). The Influence of Perceived Service Quality on Repurchase and Customer Satisfaction as Variable Intervening in Fast Food Restaurant in Surabaya.Journal of Marketing Management, Vol. 12, No. 2,

${ }^{30}$ Cendriono (2017). The Effect of Service Quality on Dawet Jabung Repurchase as seen from Customer Satisfaction as a Mediation Variable. Journal of Accounting and Tax, 18 (02)
} 
theoretically explain the relationship between the independent and dependent variables

Based on the previously discussed theory regarding service quality, repurchase interest, and customer satisfaction, a research model can be drawn up which can be described as follows:

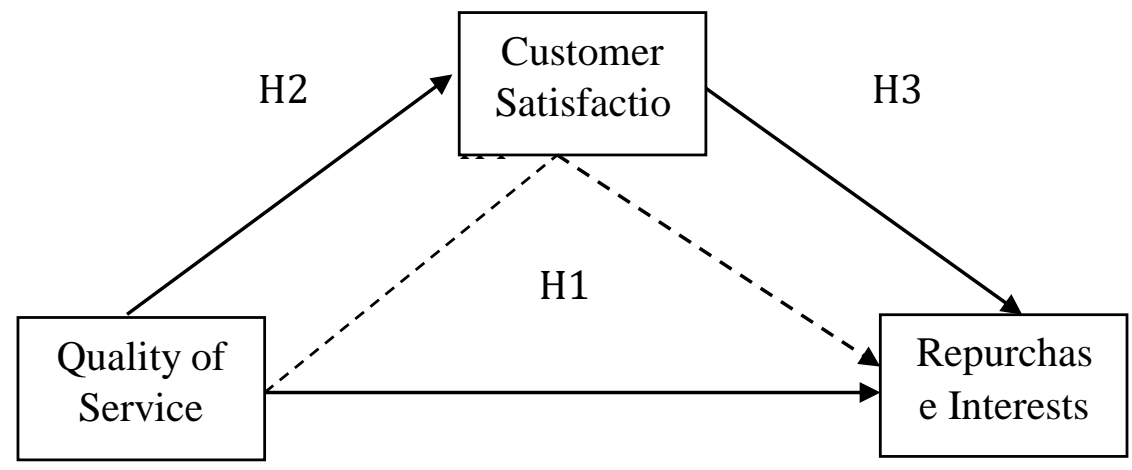

\section{RESEARCH METHODS}

Types of research

This research is a type of quantitative research and is descriptive in nature, namely research in the form of numbers and analysis of data processing research results used is statistical analysis. This approach is empirical, objective, measurable, rational, systematic, and provides information about the relationship between two or more variables, with the aim of testing predetermined hypotheses.

This research was conducted to see the effect of service quality on repurchase interest through customer satisfaction.

\section{Research variable}

research variable is an attribute or nature or value of a person, object, or activity that has certain variations determined by researchers to be studied and drawn conclusions.

The variables to be analyzed in this study consisted of three types, namely 
1. Independent Variable

Independent variables are variables that affect or cause the change or the emergence of the dependent variable $^{31}$ (Sugiyono, 2012: 59). The independent variable in this study is Service Quality

2. Dependent Variable

Dependent variables are variables that are affected or that are the result, because of the independent variables ${ }^{32}$. The dependent variable in this study is Repurchase Interest.

3. Intervening / mediating variables

Intevening / mediation variables are variables that theoretically affect the relationship between the independent variable and the dependent variable into an indirect relationship and cannot be observed and measured. This variable is an intermediate variable that lies between the independent and dependent variables, so that the independent variable does not directly affect the change or emergence of the dependent variable 33 . In this study, the intervening / mediating variable is Customer Satisfaction

\section{RESULT AND ANALYSIS}

\section{Multiple Linear Regression}

In this study, using multiple linear regression analysis to test the hypothesis in the study, namely H3 and H4. Multiple linear regression analysis to test the service quality variable (X) on Repurchase Interest (Y) is mediated by Customer

\footnotetext{
${ }^{31}$ Sugiyono.2012. Business Research Methods. Bandung: Alfabeta

32 Sugiyono.2012. Business Research Methods. Bandung: Alfabeta

33 Sugiyono.2016. Educational research methods approach quantitative, qualitative, and R \& D. Bandung: Alfabeta.
} 
Satisfaction (Z). The results of multiple linear regression analysis are as follows:

a. Effect of Service Quality (X) on Repurchase Interest (Y) in Mediation by Customer Satisfaction (Z)

After testing using SPSS version 20.0, the results are listed in table 5.14 below:

Results of Analysis of the Influence of Service Quality on Repurchase Interest in Mediation by Customer Satisfaction

\section{Coefficientsa}

\begin{tabular}{|c|c|c|c|c|c|}
\hline \multirow[t]{2}{*}{ Model } & \multicolumn{2}{|c|}{$\begin{array}{l}\text { Unstandardized } \\
\text { Coefficients }\end{array}$} & \multirow{2}{*}{$\begin{array}{l}\text { Standardize } \\
\text { d } \\
\text { Coefficients } \\
\text { Beta }\end{array}$} & \multirow[t]{2}{*}{$\mathrm{t}$} & \multirow[t]{2}{*}{ Sig. } \\
\hline & B & Std. Error & & & \\
\hline (Constant) & 1,489 &, 378 & & 3,936 &, 000 \\
\hline 1 total_X &, 023 &, 080 &, 021 &, 295 & , 769 \\
\hline total_Z &, 579 &, 074 &, 559 & 7,779 &, 000 \\
\hline
\end{tabular}

a. Dependent Variable: total_Y

Source: Primary Data Processed 2019, Appendix F

Based on table 5.14, it is obtained the results of multiple linear regression analysis seen from Unstandardized Coefficients, are as follows: $\mathrm{Y}=1.489+$ $0.23 \mathrm{X} 1+0.579 \mathrm{X} 2$. From the multiple linear regression equation it can be interpreted as follows:

1) In the regression equation above, the constant value (a) is 1.489. This means that if the independent variables Service Quality (X) and Customer Satisfaction (Z) are equal to zero (0) then Repurchase Interest (Y) is worth 1.489. 
2) The Service Quality variable has a positive influence on Repurchase Interest (Y) with a regression coefficient of 0.23 if the Service Quality (X) is one unit, then Repurchase Interest (Y) increases by 0.23 .

3) The Consumer Satisfaction variable (Z) has a positive effect on Repurchase Interest (Y) with a regression coefficient of 0.579 . If Customer Satisfaction (Z) is one unit, then Repurchase Interest ( $\mathrm{Y}$ ) increases by 0.579 .

\section{Hypothesis test}

\section{a. T test}

The $t$ statistical test shows how far the influence of each independent variable individually is in explaining the variation in the dependent variable. The $t$ test is used to test whether there is an influence or relationship between the independent variable on the dependent variable individually $(X)$ on the dependent variable $(\mathrm{Y})$, it is said to be significant if $\mathrm{t}$-count $>\mathrm{t}$ table. Or the opposite is said to be insignificant if $\mathrm{t}$-count $<\mathrm{t}$ table. The results of the $t$ test are as follows:

\section{1) Effect of Service Quality (X) on Repurchase Interest (Y)}

The first hypothesis test using simple linear regression analysis, namely Service Quality (X) on Repurchase Interest (Y) is carried out by comparing the t-count obtained from table 5.14 in column $t$ with $\mathrm{t}$-table obtained from $\mathrm{df}=\mathrm{nk}$ where $\mathrm{n}$ is the number of samples and $\mathrm{k}$ is the number of independent variables. In this study, the number of samples $(n)=150$, then $\mathrm{df}=150-1=149$ with $\alpha=5 \%$, because it is a 2 -sided test, $\frac{5 \%}{2}=$ $2.5 \%$ or 0.025 to get t-table of 1.97601 (t-table attached). If $\mathrm{t}$ count> t-table then Ho is rejected and $\mathrm{Ha}$ is accepted or vice versa if t-count $<\mathrm{t}$-table then Ho is accepted and Ha is rejected. 
The t-test statistical results for the first hypothesis, namely Service Quality (X), obtained a t-count value of 2.491 with a t-table of 1.97601 . It can be seen that $t$-count (2.491)>ttable (1.97601) with a significance level of $0.014(\mathrm{p}<0.05)$, the conclusion is that Ho is rejected and Ha is accepted. So from the $\mathrm{t}$ test it can be explained that Service Quality (X) has a significant effect on Repurchase Interest (Y) in online shopping at Lazada in Yogyakarta City. Then the first hypothesis, namely the Effect of Service Quality (X) on Repurchase Interest (Y) is accepted.

\section{2) The Effect of Service Quality (X) on Customer Satisfaction (Z)}

The second hypothesis test using simple linear regression analysis, namely Service Quality (X) on Customer Satisfaction (Z) is done by comparing the t-count obtained from table 5.15 in column $\mathrm{t}$ with $\mathrm{t}$-table obtained from $\mathrm{df}=\mathrm{nk}$ where $\mathrm{n}$ is the number of samples and $\mathrm{k}$ is the number of independent variables. In this study, the number of samples $(n)=150$, then $\mathrm{df}=150-1=149$ with $\alpha=5 \%$, because it is a 2 -sided test, $\frac{5 \%}{2}=$ $2.5 \%$ or 0.025 to get t-table of 1.97601 ( $\mathrm{t}$-table attached). If $\mathrm{t}$ count> t-table then Ho is rejected and Ha is accepted or vice versa if t-count $<\mathrm{t}$-table then Ho is accepted Ha is rejected.

The t-test statistical results for the second hypothesis, namely Service Quality (X), obtained a t-count value of 4.126 with a t-table of 1.97601 . It can be seen that $t$-count (4.126)>ttable (1.97601) with a significance level of 0.000 ( $p<0.05)$, then the conclusion is Ho is rejected and Ha is accepted. So from the $t$ test it can be explained that Service Quality (X) has a significant effect on Customer Satisfaction (Z) in online shopping at Lazada in Yogyakarta City. Then the second hypothesis, namely the Effect of Service Quality (X) on Customer Satisfaction (Z) is accepted. 


\section{3) Effect of Consumer Satisfaction (Z) on Repurchase Interest ( $\mathrm{Y}$ )}

The third hypothesis test using multiple linear regression analysis, namely Customer Satisfaction (Z) on Repurchase Interest $(\mathrm{Y})$ is done by comparing the t-count obtained from table 5.16 in column t with t-table obtained from $\mathrm{df}=\mathrm{nk}$ where $\mathrm{n}$ is the number of samples and $\mathrm{k}$ is the number of independent variables. In this study the number of samples (n) $=150$, then $\mathrm{df}=150-2=148$ with $\alpha=5 \%$, because it is a 2 sided test, $\frac{5 \%}{2}=2.5 \%$ or 0.025 to get t-table of 1.97612 (t-table attached). If $\mathrm{t}$-count $>\mathrm{t}$-table then $\mathrm{Ho}$ is rejected and $\mathrm{Ha}$ is accepted or vice versa if $\mathrm{t}$-count $<\mathrm{t}$-table then Ho is accepted and $\mathrm{Ha}$ is rejected.The t-test statistical results for the third hypothesis, namely Customer Satisfaction (Z), obtained a tcount value of 7.779 with a t-table of 1.97612 . It can be seen that t-count $(7,779)>t$-table $(1.97612)$ with a significance level of 0.000 ( $p<0.05$ ), then the conclusion is Ho is rejected and Ha is accepted. So from the t test it can be explained that Customer Satisfaction (Z) has a significant effect on Repurchase Interest (Y) in online shopping at Lazada in Yogyakarta City. Then the third hypothesis, namely the Effect of Customer Satisfaction (Z) on Repurchase Interest (Y) is accepted

Effect of Service Quality (X) on Repurchase Interest (Y) 
F test results and the level of significance of the influence of service quality on repurchase interest

ANOVA

\begin{tabular}{|l|l|l|l|l|l|}
\hline Model & $\begin{array}{l}\text { Sum of } \\
\text { Squares }\end{array}$ & df & $\begin{array}{l}\text { Mean } \\
\text { Square }\end{array}$ & F & Sig. \\
\hline \multicolumn{1}{|l|}{$\begin{array}{l}\text { Regression } \\
1\end{array}$} & 3,486 & 1 & 3,486 & 6,20 & 6 \\
Residual & 83,143 & 148 &, 562 & $014 \mathrm{~b}$ \\
Total & 86,629 & 149 & & & \\
\hline
\end{tabular}

a. Dependent Variable: total_Y

b. Predictors: (Constant), total_X

The first hypothesis test using simple linear regression analysis, namely Service Quality (X) on Repurchase Interest (Y) is carried out by comparing the F-count obtained from table 5.17 in column $\mathrm{F}$ with the F-table obtained from $\mathrm{df}=\mathrm{nk}-1$ where $\mathrm{n}$ is number of samples and $\mathrm{k}$ is the number of independent variables. In this study the number of samples (n) $=150$, then $\mathrm{df}=150-1-1=148(1 ; 148)$ with $\alpha=5 \%$,so it gets The F-table is 3.91 ( $F$ table is attached). If $\mathrm{F}$-count $>\mathrm{F}$-table then Ho is rejected and Ha is accepted or vice versa if F-count $<$ Ftable then Ho is accepted and Ha is rejected.

The results of the F-test statistic for the first hypothesis, namely Service Quality (X), obtained an F-count value of 6.206 with an F-table of 3.91. It can be seen that F-count (6.206)> Ftable (3.91) with a significance level of $0.014(\mathrm{p}<0.05)$, then the conclusion is Ho is rejected and $\mathrm{Ha}$ is accepted. So that the F test can illustrate that Service Quality (X) has a significant effect on Repurchase Interest (Y) in online shopping at Lazada in Yogyakarta City. Then the first hypothesis, namely the Effect of Service Quality (X) on Repurchase Interest (Y) is accepted. 


\section{Effect of Service Quality (X) on Customer Satisfaction (Z) F Test Results and the Significance Level of Service Quality on Customer Satisfaction}

ANOVA

\begin{tabular}{|c|c|c|c|c|c|}
\hline Model & $\begin{array}{l}\text { Sum of } \\
\text { Squares }\end{array}$ & $d f$ & $\begin{array}{l}\text { Mean } \\
\text { Squar } \\
\text { e }\end{array}$ & $\mathrm{F}$ & Sig. \\
\hline $\begin{array}{ll} & \text { Regressio } \\
1 & \mathrm{n} \\
\text { Residual } \\
\text { Total }\end{array}$ & $\begin{array}{l}8,315 \\
72,276 \\
80,591\end{array}$ & $\begin{array}{l}1 \\
148 \\
149\end{array}$ & $\begin{array}{l}8,315 \\
, 488\end{array}$ & $\begin{array}{l}17,02 \\
7\end{array}$ & ' \\
\hline
\end{tabular}

a. Dependent Variable: total_Z

b. Predictors: (Constant), total_X

\section{Source: Primary Data Processed 2019, Appendix F}

The second hypothesis test using simple linear regression analysis, namely Service Quality (X) to Customer Satisfaction $(\mathrm{Z})$ is done by comparing the F-count obtained from table 5.18 in column $\mathrm{F}$ with the F-table obtained from $\mathrm{df}$ $=\mathrm{nk}-1$ where $\mathrm{n}$ is the number sample and $\mathrm{k}$ is the number of independent variables. In this study the number of samples (n) $=150$, then $\mathrm{df}=150-1-1=148(1 ; 148)$ with $\alpha=5 \%$, so it gets The F-table is 3.91 (F-table is attached). If F-count> F-table then $\mathrm{Ho}$ is rejected and $\mathrm{Ha}$ is accepted or vice versa if $\mathrm{F}$-count $<$ F-table then Ho is accepted and Ha is rejected.

The results of the F-test statistic for the second hypothesis, namely Service Quality (X), obtained an F-count value of 17.027 with an F-table of 3.91. It can be seen that Fcount (17.027) > F-table (3.91) with a significance level of 0.000 ( $p<0.05$ ), then the conclusion is Ho is rejected and $\mathrm{Ha}$ is accepted. So that the F test can illustrate that Service Quality $(\mathrm{X})$ has a significant effect on Customer Satisfaction (Z) in 
online shopping at Lazada in Yogyakarta City. Then the second hypothesis, namely the Effect of Service Quality (X) on Customer Satisfaction (Z) is accepted.

\section{1) Effect of Service quality (X) on Repurchase Interest (Y) Mediated by Customer Satisfaction (Z)}

F Test Results and the Significance Level of Service Quality on Repurchase Interest in Mediation by Customer Satisfaction

ANOVA

\begin{tabular}{|c|c|c|c|c|c|}
\hline Model & $\begin{array}{l}\text { Sum of } \\
\text { Squares }\end{array}$ & $\mathrm{df}$ & $\begin{array}{l}\text { Mean } \\
\text { Square }\end{array}$ & $\mathrm{F}$ & Sig. \\
\hline $\begin{array}{ll} & \text { Regressio } \\
1 & \mathrm{n} \\
& \text { Residual } \\
& \text { Total }\end{array}$ & $\begin{array}{l}27,732 \\
58,896 \\
86,629\end{array}$ & $\begin{array}{l}2 \\
147 \\
149\end{array}$ & $\begin{array}{l}13,866 \\
, 401\end{array}$ & $\begin{array}{l}34,60 \\
9\end{array}$ & $000 \mathrm{~b}$ \\
\hline
\end{tabular}

a. Dependent Variable: total_Y

b.Predictors: (Constant), total_Z, total_X

The fourth hypothesis test uses multiple linear regression analysis, namely Service Quality (X) on Repurchase Interest $(\mathrm{Y})$ mediated by Customer Satisfaction (Z) is done by comparing the F-count obtained from table 5.19 in column $\mathrm{F}$ with the F-table obtained from $\mathrm{df}=\mathrm{nk}-1$ where $\mathrm{n}$ is the number of samples and $\mathrm{k}$ is the number of independent variables. In this study the number of samples $(\mathrm{n})=150$, then $\mathrm{df}=150-2-1$ $=147(2 ; 147)$ with $\alpha=5 \%$,so it gets F-table of 3.06 ( $\mathrm{F}$ table attached). If F-count> F-table then $\mathrm{Ho}$ is rejected and $\mathrm{Ha}$ is accepted or vice versa if F-count $<$ F-table then Ho is accepted and $\mathrm{Ha}$ is rejected. 
The results of the F test statistics for the third and fourth hypotheses, namely Service Quality (X), and Customer Satisfaction (Z), obtained an F-count value of 34.609 with an Ftable of 3.06. It can be seen that F-count (34.609)> F-table (3.06) with a significance level of $0.000(\mathrm{p}<0.05)$, then the conclusion is Ho is rejected and $\mathrm{Ha}$ is accepted. So that the $\mathrm{F}$ test can illustrate that Service Quality (X) has a significant effect on Repurchase Interest (Y) mediated by Customer Satisfaction (Z) in online shopping at Lazada in Yogyakarta City. Then the fourth hypothesis, namely the Effect of Service Quality (X) on Repurchase Interest (Y) Mediated by Customer Satisfaction (Z) is accepted.

\section{CONCLUSION}

Based on the results of research and discussion of Service Quality (X) Against Repurchase Interest (Y) with Customer Satisfaction (Z) as a Mediation Variable, the following conclusions can be drawn:

1. Service Quality Variable (X) has a significant effect on Repurchase Intention (Y).

2. Service Quality Variable (X) has a significant effect on Customer Satisfaction (Z).

3. Consumer Satisfaction Variable (Z) has a significant effect on Repurchase Interest $(Y)$.

4. Based on the analysis conducted by comparing the direct effect and the indirect effect, the result shows that Customer Satisfaction (Z) is fully mediated between Service Quality (X) and Repurchase Interest (Y). This is because when the direct effect and the indirect effect are compared, the coefficient value of Service Quality (X) has decreased, and has a significance level that was initially significant to insignificant. 


\section{REFEENCES}

Aditya L (2008) Analysis of the Effect of Service Quality on Repurchase Interest in Empirical Studies at Pt.Sriwijaya Air, Semarang District. Journal of Business Strategy Vol. 17 No. 2

Arfiani \& Herman (2015). The Effect of Product Quality and Service Quality on Customer Satisfaction and Buyback Intention at Padamcdonald's Alauddin Makassar. Journal of Organization and Management Vol 3 September, 2015

Agustiani (2014).The effect of customer satisfaction on the interest in buying re-purchases on the Lion Air airline in Jakarta. Journal of Economics, Management and Accounting Vol. 9 No.3

Aliyyah (2017). The influence of service quality on customer satisfaction on consumers of The Little A Coffee Shop Sidoarjo. Journal of Business Administration (JAB) Vol. 51 No. 2

Cendriono (2017). The Effect of Service Quality on Dawet Jabung Repurchase as seen from Customer Satisfaction as a Mediation Variable. Journal of Accounting and Tax, 18 (02)

Chandra (2014). The Influence of Satisfaction as a mediation of service quality on Consumer Purchase Intention at the Boga-Bogi Restaurant, Surakarta. September 2014 Edition of Informatics Vol. 1 No. 21

Cronin, J Joseph, Jr, and Steven A Taylor (1992). Measuring Service Quality: A Reexamination and Extension, Journal Of Marketing vol 56.

Curtis T, et al (2011). Customer Satisfation, Loyalty And Repurchase: Some Evidence From Apparel Consumers. Department of Management, Marketing \& Operations 
Destiana (2018). The influence of service quality on guest satisfaction at Niagara Parapat Hotel, North Sumatra Province.JOM FISIP Vol. 5 No. 1

Dian, et al (2014). The Influence of Store Image on Customer Satisfaction and Repurchase Intention at Circle $\mathrm{K}$ in Denpasar City. Journal of Business Strategy Management and Entrepreneurship Vol. 8 No.1.

Felita S \& Dr. Hartono S (2013). The Effect of Service Quality on Customer Satisfaction of Penyet Ria Chicken Restaurant. Petra's Journal of Marketing ManagementVol. 1, No. 2

Fendriawan (2017). The Effect of Service Quality on Ufit Socks

Consumer Satisfaction. Journal of Management and Business Start-Up Volume 2, Number 3

Ferdinand, A. 2002. Structural Equation Modeling in Management Research, 2nd edition BP UDIP: Semarang.

Ghazali. 2009. Application of Multivariate Analysis with SPSS

Program. Semarang: Diponegoro University.

Habibillah (2018). The Influence of Customer Satisfaction as an Intervening Variable on the Relationship between

Service Quality and Repurchase of Freight

Forwarding Companies: Surakarta

Hikmatul (2015) The Effect of Service Quality on Consumer Purchase Intention at Indomaet and Alfamart Minimarkets. Malik Ibrahim State Islamic University, Malang

https://www.google.co.id/searchW\&Sgroupresearchlazada accessed on 10 November 2018

https://www.google.co.id/search?q=detik.com+user+ecomer s+lazada accessed on 10 November 2018.

http://www.topbrand-award.com/top-brand-survey/surveyresult/top_brand_index_2018_fase_2 Retrieved November 10, 2018 
https://id.m.wikipedia.org/wiki/Lazada Indonesia accessed on 20 November 2018.

Ida M. The Effect of Perceptions of Quality and Customer Satisfaction on Repurchase Intention of Pepsodent Toothpaste : Faculty of Economics, Unika Santo Thomas, North Sumatra

Inda R (2019). The Effect of Service Quality and Ease of Use on

Repurchase Intentions with Satisfaction as a

Mediation Variable. Journal of Management Science

Volume 7 Number 1

Januar EP \& Ai Lili (2016). The Influence of Service Quality on Customer Satisfaction at JNE Bandung Branch. Journal of Management Vol. 11 No. 2.

Jocellynne (2018). The Influence of Perceived Service Quality on Repurchase and Customer Satisfaction as Variable Intervening in Fast Food Restaurant in Surabaya.Journal of Marketing Management, Vol. 12, No. 2,

Joseph, F Hair., JR., Rolp E Anderson, Ronald L, Tatham and, William L Black. 2010. Multivariate data analysis, 7 / e. USA: Prentice Hall International, Inc.

Kenny \& Nyoman (2018). The Influence of Trust, Price Perception, and Attitude Toward Purchase Intention on the Lazada Site. E-journal of Management of Udayana University, Vol. 7, No.8,2018

Kotler, P. \& Keller, KL (2006). Marketing management. (12th edition). Upper Saddle River: Pearson Education, Inc. Blue (2008). Analysis of the Effect of Service Quality on Repurchase Interest (Empirical Study at Pt. Sriwijaya Air Semarang District). Journal of Business Strategy Vol. 17 No. 2.

Murakami (2017). The Effect of Service Quality on Consumer Repurchase Interest at Asuka Restaurant Cibitung: Bina Nusantara University, Bekasi Utara. 
M. Irzad (2018). The Influence of Customer Satisfaction on Food Repurchase Interest at Ayam Bakar Wong Solo Restaurant, Alauddin, Makassar City.Journal of Profitability, Faculty of Economics and Business Volume 2 No 1

M Wildan (2016). The Influence of Brand Image, Brand Trust and Customer Satisfaction on Repurchase Interest of The Executive Women's Clothing in Surabaya.Schoolah Higher Education of Economics at Perbanas, Surabaya

M. Yusri (2013). Effect of service quality on customer satisfaction Gool Futsal Mangga Dua Surabaya. University of Surabaya Student Scientific Journal Vol.2 No.1

Nilasari \& Istiatin (2015). The influence of service quality on customer satisfaction at the dealer PT. Ramayana Motor Sukoharjo. Paradigm Journal Vol. 13, No. 01.

Niken \& Retno (2014). The Relationship Between Awareness, Perceived Quality, Brand Trust and Purchase Intention for Green Products. Journal of Management \& Business Vol.5 No.1.

Nurhayati \& Wahyu W (2012). Analysis of Factors Affecting Public Purchase Interest Against Value Added Mobile Products Vol. 8, No.2, March

Oktaviani (2015) The Impact of Quality of Service on Repurchase Intention (Study on Trans Retail Carrefour in Bandung). e-Proceeding of Management: Vol. 2, No.3

Parasuraman, A, Berry, LL., Zeithanil, VA., And Berry, Leonard L. 1998. "SERVQUAL: A Multi-item Scale to Measuring Consumer Perceptions of Service Quality", Journal of Retailing, Vol 64 No.1 
Pratiwi, et.al (2016). The Effect of Service Quality and Customer Satisfaction on the Intention to Buy Drugs at the Orchid Pharmacy Depo Dr. Hasan Sadikin, Bandung. Indonesian Journal of Clinical Pharmacy Vol.5 No. 1

Prilando (2017) The Effect of Service Quality on Repurchase Interest at Legend Coffe Yogyakarta. Sanata Dharma University, Yogyakarta

Putri, et.al (2015) Analysis of Service Quality on Consumer Purchase Intention (Case Study of Gramedia Bookstore Colonel Atmo Palembang). STIE Multi Data, Palembang.

Rahmat H (2015). The effect of consumer satisfaction on the decision to purchase Philips lamps (case study on Telkom University students). Ecodemica V ol 3. N o.1 Ramli Akbar. The Effect of Customer Satisfaction and Trust on Repurchase Intentions at Online Stores. Department of Management, FEB UMM

Rendi \& Kezia (2014) The effect of E-service quality on consumer buying interest (case study on the Korean Denim website). Journal of Management, Vol. 13, No. 2.

Riko (2013). The Effect of Service Quality and Perceived Value on Repurchase Intention through Mediation of Customer Satisfaction at Solaria Restaurant in Surabaya. Journal of Business And Banking Volume 3, No. 2.

Rustika A \& M Wahyuddin (2007). Analysis of the Influence of Service Quality on Customer Satisfaction at Matahari Department Store in Solo Grand Mall.Journal of Resource Management Economics Vol. 5, No. 1.

Now, Uma. 2006. Research Methods for Business: A Skill Building Approach. 3th ed., New York: John Willey \& Sons, Inc. 
Sugiyono.2004. Research methods. Bandung: Alfabeta

.2006. Qualitative and Quantitative Research Methods and R \& D. Bandung: Alfabeta

.2008. Sattistik For Research. Bandung: Alfabeta

.2012. Business Research Methods. Bandung: Alfabeta

.2014. Educational research methods approach quantitative, qualitative, and R \& D. Bandung: Alfabeta.

.2016. Educational research methods approach quantitative, qualitative, and R \& D. Bandung: Alfabeta.

. 2017. Statistics for Research. Bandung: Alfabeta.

S Wibowo, et.al (2013) The Influence of Service Quality Perception on Repurchase Intention at Gramedia Bookstore Yogyakarta. Journal of Economics, Volume 4 No 1

Teuku Fadhil Magistra (2015). The Effect of Service Quality and Satisfaction on B2C E-commerce Consumer Loyalty in South Jakarta. Bakrie Journal Vol. 3 No.3.

Tjiptono, Fandy. 2000. Principles of Total Quality Service. Yogyakarta: Andi Offset.

. 2003. Principles of Total Qualiti Service. Yogyakarta: Andi Offset.

. 2004. Service Management, First Edition. Yogyakarta: Andi Offset.

. 2006, Service Management, Publisher Andi, Yogyakarta 
Tjiptono and Chandra. 2011. Service, Quality and Satisfaction (3rd ed). Yogyakarta: Andi.

Wendo (2018) The Effect of Service Quality on Repurchase Interest at Puti Minang Raja Basa Restaurant in Bandar Lampung. UIN Raden Intan, Lampung.

Widya Oktaviani (2015). The Impact of Quality of Service on Repurchase Intention (Study on Trans Retail Carrefour in Bandung. E-Proceeding of Management: Vol.2, No.3.

Wijaya, Toni. 2013. Economic and Business Research Methodology. Yogyakarta: Graha Science.

WT Hardianto, et.al (2012). Analysis of the Effect of Service Quality on Customer Satisfaction in Electricity Account Payments at the Customer Service Unit in Probolinggo. Reform Journal, Volume 2, Number 2

Yohana \& Sahat (2012). Factors Affecting the Purchase Intention of Food and Beverage Products for Small and Medium Enterprises, Tangerang Regency. Journal of Management and Entrepreneurship Vol. 14 No.2 September 2012.

Yudiana (2016). The Effect of Service Quality With Customer Satisfaction At Pt. Pusri Palembang Ppd Lampung. Journal of Islamic Economics and Business Volume 1, Number 2

Zainul (2016). The Influence of Brand Image on Purchase Intention and Purchase Decision, a survey of students of the 2013/2014 class of business administration study program, Faculty of Administrative Sciences, Malang University of Malang, Indosat Ooredoo buyers Journal of Business Administration Vol.40 no.1 November 2016. 
Zulfan A (2017) The effect of e-service quality on the interest in purchasing Muslim clothing products in Indonesian lazada from an Islamic perspective: UII Yogyakarta 